in the immediate postoperative period, especially in patients with respiratory insufficiency. The various techniques which may be employed, particularly in patients on ventilator therapy, have been fully discussed by Campbell (1967). Here again arterial blood gas analysis, along with careful monitoring of the heart rate, systemic blood pressure, and pulse pressure, is an invaluable guide when there is either unrelieved pain or oversedation with narcotic analgesics.

It is one of the important functions of an intensive care unit to initiate and develop methods of therapy such as those described above, many of which are applicable outside the intensive care area. Another function is to "feed back" information such as that revealed in the comparison of elective and emergency postoperative cases, already discussed, in order that new approaches to their treatment may be considered, as this can be done only where the problem is recognized and measured.

\section{Conclusion}

In a previous communication the experience of four years of respiratory intensive care in a large teaching hospital was reported. The present communication has amplified this in respect of more detailed comment on some of the clinical problems encountered in the intensive care of 202 postoperative patients. The value of a critical analysis of this nature cannot be overstressed in view of the fact that intensive care units of this type are increasing in number throughout the United Kingdom, yet there is a paucity of published work on the organizational aspects of the problem to guide clinicians. Recently a B.M.A. (1967) working party has undertaken a study in selected units throughout the country in an attempt to define the aims of such units and to give a factual basis for estimating their accomplishments and work. In our own experience (five years at October 1967) of respiratory intensive care the unit at the Glasgow Royal Infirmary has proved its worth in terms of improved standards of patient care, and, in addition, has revealed clinical problems which demand further investigation to explain. The unit provides an excellent opportunity to evaluate new methods of therapy, and indeed to compare the efficacy of existing methods under controlled conditions. A useful method of controlled oxygen therapy employing a simple basic mask has been developed in this way for use in the postoperative period.

\section{Summary}

Two hundred and two patients were treated in the respiratory intensive care unit at Glasgow Royal Infirmary after elective and emergency surgery. The average length of stay was 4.1 days. One hundred and thirty-one patients were admitted after elective and 71 after emergency surgery and the two groups were compared. In each group there were more males than females $(1.7: 1$ in the elective group and 2.5:1 in the emergency group) and the overall survival rates favoured the male patients. Many of the patients were found to have important underlying metabolic and cardiac disturbances, and the mortality rates in these patients differed little in the elective and emergency groups. It is suggested that a preoccupation with pre-existing respiratory problems resulted in a comparative neglect of important cardiovascular and metabolic features. Preoperative digitalization is suggested for many elderly patients with demonstrable cardiac disease even when there is no evidence of congestive failure.

REFERENCES

British Medical Association (1967). Planning Unit Report, No. 1 Campell D. (1967). Brit. \%. Anaesth., 39, 736.

Campbel, D. J. M., Telfer, A. B. M., and Fitch, W. (1967). Brit. med. Y, 4,255 .

Christiansen, J., and Brøckner, J. (1967). Dais. med. Bull., 14, 38.

Flenley, D. C., Hutchison, D. C. S., and Donald, K. W. (1963). Brit. med. $₹ ., 2,1081$.

Richard3, D. W. (1943-4). Harvey Lect., 39, 217.

\title{
Effects of Emotion and Pain on Adrenocortical Function Investigated by Hypnosis
}

\author{
STEPHEN BLACK, * M.R.C.S., L.R.C.P. ; MAX FRIEDMAN, $†$ M.B., B.CH., M.R.C.P.ED.
}

Brit. med. F., 1968, 1, 477-481

In a group of hospital patients with suspected adrenal disease it was found that when the plasma levels of 11-hydroxycorticosteroids (plasma cortisol) were estimated in the same patient at the same hour on different days variations occurred which suggested that the mental state of the patient must be taken into account in any assessment of adrenal function by this means. In all patients in this group the plasma cortisol levels were found to be higher during the first few days after admission to hospital than they were afterwards, and the levels were highest in those patients who appeared to be most anxious as a result of their admission (Friedman, 1965).

Among their many functions the adrenals are apparently concerned with the general response of the body to noxious stimuli, and a wide variety of stressful situations are now known to evoke increased production of cortisol by the adrenal cortex in response to adrenocorticotrophic hormone (A.C.T.H.) released by the anterior pituitary. However, the precise mechanisms involved in the release of A.C.T.H. are still obscure, though known to be under hypothalamic control-possibly by way of pathways from higher cortical centres (Schally et al., 1960). In the intact and unanaesthetized animal stress usually involves emotion, and emotion alone can be stressful, so that, although for experimental purposes in man it may be useful to equate stress with pain, heat, and cold, or the administration of pyrogens, or insulin-induced hypoglycaemia (Landon et al. 1963 ; Wexler et al., 1957), the role of emotion should also be taken into account when considering adrenocortical function.

Investigation of the effects of emotion has always presented difficulties in both psychology and physiology because of the problem of establishing controlled and repeatable experimental conditions; and, with regard to anxiety in man, workers in this field have tended to find their source material among such individuals as examination candidates and American rowing eights (Hill et al., 1956). However, a number of different modalities of emotion-including anxiety-can apparently be produced under controlled and repeatable experimental conditions in suitable deep-trance hypnotic subjects by hypnotic suggestion.

\footnotetext{
- Director of a Research Unit in Psychophysiology under the Nuffield Foundation at 43 Wilton Crescent, London S.W.1 t Senior Paediatric Registrar, University College Hospital, London W.C.1.
} 
We have already mentioned a change in the plasma cortisol levels as produced by suggestion under hypnosis of "fear" (Black and Friedman, 1965), and we have now investigated this further and compared the effects of suggested "anxiety" and " happiness." We then compared all such effects with those of pain and with the effect of painful stimulus after suggesting hypnotic anaesthesia, and, in one experiment, with the effect of hypnotically suggested pain in the absence of painful stimulus.

Thus four aspects of adrenocortical function in response to emotion and pain were investigated by hypnosis in terms of the plasma cortisol levels: (1) the effects of suggesting different modalities of emotion, (2) the effect of pain per se, (3) the effect of painful stimulus after suggesting hypnotic anaesthesia, and (4) the effect of hypnotically suggested pain in the absence of painful stimulus.

\section{Subjects and Hypnotic Procedures}

Eight hypnotic subjects were used (five female and three male). They were selected from approximately 160 normal healthy volunteers and found to be "deep-trance" hypnotic subjects according to the arbitrary classification of Black (1963).

Suggestions were given either as direct suggestion under hypnosis (D.S.U.H.), as in "You are frightened," or as indirect suggestion (I.S.U.H.), as in "You are frightened because the house is on fire"-and in both instances these were sometimes rendered as post-hypnotic suggestion (P.H.S.) (Black, 1965). Altogether, 24 experiments were performed: (1) four hypnotic subjects were used in 13 experiments on emotions ; (2) five in five experiments on pain ; (3) the same five in five experiments on suggested hypnotic anaesthesia; and (4) one subject in one experiment on hypnotically suggested pain-as used in (2) and (3).

\section{Experimental Procedures}

\section{Effects of Suggesting Different Modalities of Emotion}

To take account of the diurnal rhythm all experiments were started at 14.00 hours and were usually of two and a half hours' duration. The subject rested supine on a couch in a darkened room and a baseline was established over one hour. Venous blood was taken in 10-ml. volumes, starting at 14.00 hours and then 30 and 60 minutes later. At 15.00 hours the subject was hypnotized by code word and the depth of trance reinforced, as described by Black (1963). Forceful hypnotic suggestion was then given over five minutes and blood was taken at 15minute intervals for 45 minutes, after which the suggestions were cleared and the subject was woken up. In some experiments blood was then taken half-hourly during a recovery period of one hour. D.S.U.H., I.S.U.H., and P.H.S. were variously used in making the suggestions.

With reference to " anxiety," appropriate I.S.U.H. rendered as P.H.S. was given and the subject woken up; the effects were cleared under further hypnosis after 45 minutes. Thus, to create anxiety, Subject 1-the wife of a doctor in researchwas told that after 45 minutes she would tear up the "only existing copy" of a valuable scientific paper, the MS. of which was conveniently available. Subjects 2 and 3 were told that they would break an "expensive and artistically valuable vase" with a hammer-both of which were also handy. Such is the nature of P.H.S. in deep-trance hypnosis that none of these subjects had apparently any conscious knowledge of the suggestions made or the basis of the irrational motivation. It would therefore be reasonable to describe the resulting emotional state as an experimental "anxiety neurnsis." In Subiect 1 the state of euphoria produced by D.S.U.H. of "happiness" was also produced by P.H.S., and the subject was again awake during the experimental pariod.

\section{Effect of Pain per se}

The timing of blood samples and the experimental design were substantially the same as in the experiments on emotion. But after having established the baseline the subject was moved at 15.00 hours to a chair and one arm was immersed to the elbow in wet ice at $0^{\circ} \mathrm{C}$. for 30 minutes, the ice being stirred at intervals. The ischaemic pain produced in this way was extreme, and all subjects declared initially that they would be unable to endure it for 30 minutes. However, of five subjects four did and one fainted after 10 minutes. No subject suffered any permanent after-effects, though anaesthesia over the thenar eminence and some paraesthesiae in the hand and forearm lasting a few weeks were reported by three subjects and for three months by one subject.

After 30 minutes of such ischaemic pain the subject returned to the couch-though the one who fainted did so sooner-and most subjects then reported that pain of a different modality continued for a further 10 to 15 minutes of the recovery period, as normal blood flow was re-established. After immersion of the arm in ice, blood was taken at 15-minute intervals for one hour after 15.00 hours and then half an hour later.

\section{Effect of Painful Stimulus after Suggested Hypnotic Anaesthesia}

The experimental design was in all respects identical with that on pain per se, except that D.S.U.H. was given of total anaesthesia of the affected arm before immersion in ice, the same words being used throughout. The presence of appropriate anaesthesia was then diagnosed in the usual way by pinprick before continuing with the experiment.

\section{Effect of Hypnotically Suggested Pain in the Absence of Painful Stimulus}

The design of this single experiment was identical with those on pain per se and suggested hypnotic anaesthesia, except that the arm was immersed in water at $37^{\circ}$ C. and D.S.U.H. was given that it was immersed in ice and the subject suffering ischaemic pain (Subject 5).

Throughout all experiments, on each occasion before blood was taken, oral temperature, pulse rate, respiration rate, and blood pressure were recorded as in clinical practice. During all experiments under (2) and (3), when one arm was immersed in ice, the subject was also wrapped in blankets to prevent undue lowering of the body temperature. With Subjects 2, 5, and 7 experiments on pain per se were performed before those on suggested hypnotic anaesthesia, whereas with Subjects 6 and 8 the process was reversed.

\section{Chemical Technique}

The plasma cortisol concentrations were estimated by a modification of the fluorometric method of Mattingly (1962), already referred to elsewhere (Black and Friedman, 1965).

\section{Results}

\section{Effects of Suggesting Different Modalities of Emotion}

We found no observable differences which could be attributed to the form of hypnotic suggestion when given as D.S.U.H., or I.S.U.H. rendered as P.H.S. However, behavioural responses to different kinds of hypnotic suggestions of fear, anxiety, and happiness were in general fairly convincing. When D.S.U.H. of fear was given there were various displays of trembling, nailbiting, and appropriate facial expressions. In all subjects some 
increase in pulse and respiration rate was observed, together with an increased blood pressure, and in Subject 2 there was pupillary dilatation and palmar sweating-but no subjects showed pallor, excitation of the arrectores pilorum, or lid retraction when awake. After P.H.S. to tear up the MS. Subject 1 was very agitated before tearing it, and burst into tears. Given P.H.S. to break the vase, Subject 2 was apparently equally disturbed, and eventually responded in tears by hammering it forcefully into the carpet.

The results of 13 experiments on emotion as performed on four subjects are shown in Tables I-III, together with the steroid levels obtained in three subjects from 14.00 to 16.00 hours on a day when no experiment was performed. Reflecting the diurnal rhythm and the period of rest, the resting levels show a mean fall from $20.6 \mu \mathrm{g} . / 100 \mathrm{ml}$. (range 19.4 to $22.0 \mu \mathrm{g} . /$ $100 \mathrm{ml}$.) at 14.00 hours, to $7.5 \mu \mathrm{g} . / 100 \mathrm{ml}$. (range 7.0 to $8.2 \mu \mathrm{g}$./ $100 \mathrm{ml}$.) between 15.45 and 16.00 hours. A similar fall was observed when recording the baseline in all experiments.

In spite of the emotional displays there was no significant change in response to any form of hypnotic suggestion of fear and anxiety in Subjects 1, 3, and 4 and no response to D.S.U.H. or P.H.S. of happiness was observed in Subjects 1 and 2 . (Such suggestions were not given to Subjects 3 and 4). In Subject 2 , however, there was a marked rise of $13.4 \mu \mathrm{g} . / 100 \mathrm{ml}$. after D.S.U.H. of fear and a greater rise of $16.2 \mu \mathrm{g} . / 100 \mathrm{ml}$.

\begin{tabular}{|c|c|c|c|c|c|c|c|}
\hline \multirow[b]{2}{*}{$\begin{array}{l}\text { Time } \\
\text { of Day }\end{array}$} & \multirow[b]{2}{*}{$\begin{array}{l}\text { Min- } \\
\text { utes } \\
\text { of } \\
\text { Experi- } \\
\text { ment }\end{array}$} & \multicolumn{6}{|c|}{ Plasma Cortisol ( $\mu \mathrm{g} . / 100 \mathrm{ml})}$. \\
\hline & & $\begin{array}{l}\text { Normal } \\
\text { Diurnal } \\
\text { Change }\end{array}$ & $\begin{array}{l}\text { During } \\
\text { D.S.U.H. } \\
\text { of Fear }\end{array}$ & $\begin{array}{l}\text { During* } \\
\text { I.S.U.H.I } \\
\text { P.H.S. } \\
\text { of } \\
\text { Anxiety }\end{array}$ & $\begin{array}{c}\text { During* } \\
\text { D.S.U.H. } \\
\text { of } \\
\text { Anxiety }\end{array}$ & $\begin{array}{c}\text { During* } \\
\text { D.S.U.H. } \\
\text { of } \\
\text { Happi- } \\
\text { ness }\end{array}$ & $\begin{array}{c}\text { During* } \\
\text { P.H.S. } \\
\text { of } \\
\text { Happi- } \\
\text { ness }\end{array}$ \\
\hline 14.00 & $\begin{array}{r}0 \\
30\end{array}$ & $\begin{array}{l}20 \cdot 4 \\
15 \cdot 6\end{array}$ & $\begin{array}{l}24.8 \\
17.6\end{array}$ & $\begin{array}{l}22 \cdot 2 \\
16 \cdot 2\end{array}$ & $\begin{array}{l}14 \cdot 8 \\
10 \cdot 8\end{array}$ & $\begin{array}{l}17 \cdot 4 \\
14 \cdot 0\end{array}$ & $\begin{array}{r}10 \cdot 0 \\
7 \cdot 4\end{array}$ \\
\hline 15.00 & $\begin{array}{r}60 \\
75 \\
90 \\
105\end{array}$ & $\begin{array}{r}11 \cdot 8 \\
8 \cdot 8 \\
7 \cdot 0\end{array}$ & $\begin{array}{r}13 \cdot 2 \\
11 \cdot 2 \\
8 \cdot 0 \\
7 \cdot 8\end{array}$ & $\begin{array}{r}13 \cdot 3 \\
11 \cdot 0 \\
9 \cdot 8 \\
8 \cdot 2\end{array}$ & $\begin{array}{l}9 \cdot 4 \\
6 \cdot 8 \\
5 \cdot 6 \\
6 \cdot 6\end{array}$ & $\begin{array}{r}10.9 \\
8.4 \\
7.6 \\
6.5\end{array}$ & $\begin{array}{l}6 \cdot 4 \\
6 \cdot 0 \\
5 \cdot 2 \\
5 \cdot 4\end{array}$ \\
\hline 16.00\{ & $\begin{array}{l}120 \\
165\end{array}$ & & $7 \cdot 0$ & & $5 \cdot 6$ & & \\
\hline
\end{tabular}

\begin{tabular}{|c|c|c|c|c|c|}
\hline \multirow[b]{2}{*}{$\begin{array}{l}\text { Time } \\
\text { of Day }\end{array}$} & \multirow[b]{2}{*}{$\begin{array}{l}\text { Minutes of } \\
\text { Experiment }\end{array}$} & \multicolumn{4}{|c|}{ Plasma Cortisol ( $\mu \mathrm{g} . / \mathrm{ml})}$. \\
\hline & & $\begin{array}{l}\text { Normal } \\
\text { Diurnal } \\
\text { Change }\end{array}$ & $\begin{array}{l}\text { During* } \\
\text { I.S.U.H.I } \\
\text { P.H.S. of } \\
\text { Anxiety }\end{array}$ & $\begin{array}{c}\text { During** } \\
\text { D.S.U.H. } \\
\text { of } \\
\text { Fear }\end{array}$ & $\begin{array}{l}\text { During* } \\
\text { D.S.U.H. } \\
\text { of } \\
\text { Happiness }\end{array}$ \\
\hline 14.00$\}$ & $\begin{array}{r}0 \\
30\end{array}$ & $\begin{array}{l}19 \cdot 4 \\
14 \cdot 0\end{array}$ & $\begin{array}{l}16 \cdot 6 \\
14 \cdot 8\end{array}$ & $\begin{array}{l}16 \cdot 2 \\
16 \cdot 4\end{array}$ & $\begin{array}{l}21 \cdot 6 \\
19 \cdot 4\end{array}$ \\
\hline 15.00$\}$ & $\begin{array}{r}60 \\
75 \\
90 \\
105\end{array}$ & $\begin{array}{r}10 \cdot 6 \\
11 \cdot 3 \\
8 \cdot 2\end{array}$ & $\begin{array}{l}11.8 \\
17.6 \\
19.6 \\
28.0\end{array}$ & $\begin{array}{l}13 \cdot 8 \\
18 \cdot 0 \\
23 \cdot 4 \\
27 \cdot 2\end{array}$ & $\begin{array}{l}16.4 \\
15 \cdot 0 \\
11.4 \\
15.8\end{array}$ \\
\hline 16.00\{ & $\begin{array}{l}120 \\
165\end{array}$ & $7 \cdot 2$ & & $19 \cdot 2$ & \\
\hline
\end{tabular}

* Hypnotic suggestion begun at 15.00 hours.

TABLE III.-Variations in Plasma Cortisol Concentration During Hypnotically Induced Emotion in Subjects 3 and 4

\begin{tabular}{|c|c|c|c|c|}
\hline \multirow{3}{*}{$\begin{array}{c}\text { Time } \\
\text { of Day }\end{array}$} & \multirow{3}{*}{$\begin{array}{c}\text { Minutes } \\
\text { of } \\
\text { Experiment }\end{array}$} & \multicolumn{3}{|c|}{ Plasma Cortisol ( $\mu \mathrm{g} . / 100 \mathrm{ml})}$. \\
\hline & & \multicolumn{2}{|c|}{ Subject 3} & \multirow{2}{*}{$\begin{array}{c}\text { Subject } 4 \\
\text { During** } \\
\text { D.S.U.H. } \\
\text { of Fear }\end{array}$} \\
\hline & & $\begin{array}{l}\text { Normal } \\
\text { Diurnal } \\
\text { Change }\end{array}$ & \begin{tabular}{|l|}
$\begin{array}{c}\text { During** } \\
\text { I.S.U.H./P.H.S. } \\
\text { of Anxiety }\end{array}$ \\
\end{tabular} & \\
\hline 14.00 & $\begin{array}{r}0 \\
30\end{array}$ & $\begin{array}{l}22 \cdot 0 \\
13 \cdot 8\end{array}$ & $\begin{array}{l}20.0 \\
11.8\end{array}$ & $\begin{array}{l}15 \cdot 2 \\
13 \cdot 2\end{array}$ \\
\hline 15.00 & $\begin{array}{l}60 \\
75 \\
90\end{array}$ & $\begin{array}{r}12 \cdot 0 \\
10 \cdot 0 \\
8 \cdot 2\end{array}$ & $\begin{array}{l}9 \cdot 0 \\
6 \cdot 0 \\
7 \cdot 3\end{array}$ & $\begin{array}{l}10 \cdot 4 \\
10 \cdot 2 \\
10 \cdot 0\end{array}$ \\
\hline 16.00 & $\begin{array}{l}120 \\
165\end{array}$ & $7 \cdot 4$ & $\begin{array}{l}5 \cdot 2 \\
6 \cdot 2\end{array}$ & $\begin{array}{l}9 \cdot 2 \\
8 \cdot 0\end{array}$ \\
\hline
\end{tabular}

after I.S.U.H. rendered as P.H.S. of anxiety as described. These positive results are shown in Fig. 1.

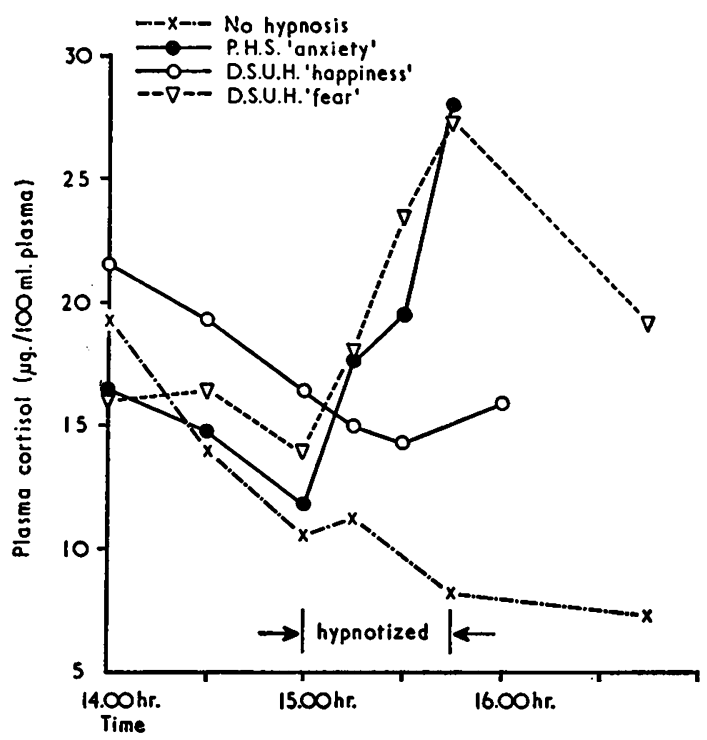

FIG. 1-Responses of Subiect 2 (F.) to D.S.U.H. of happiness followed the same pattern as the normal diurnal rhythm of the plasma cortisol levels when no hypnosis was induced the plasma cortisol levels when no hypnosis was all results were negative, D.S.U.H. of fear and P.H.S. of anxiety in Subject 2 produced marked rises in the plasma cortisol.

\section{2 and 3. Effect of Pain per se and Painful Stimulus after Suggesting Hypnotic Anaesthesia}

Whereas behavioural responses to pain per se and the subjective reports indicated that this was extreme, no such responses were observed after D.S.U.H. of anaesthesia, and all subjects reported that they felt "nothing" in the affected arm. During pain per se pulse, respiration rate, and the blood pressure were variable, and after D.S.U.H. of anaesthesia no significant change was observed in these values. In spite of precautions a slight fall in oral temperature was recorded in all subjects during arm immersion in ice in both sets of experiments, giving a mean fall of $0.6^{\circ} \mathrm{C}$. (range $0.2-1.3^{\circ} \mathrm{C}$.).

The results of five experiments on pain per se and suggested hypnotic anaesthesia are shown in Table IV. Though some

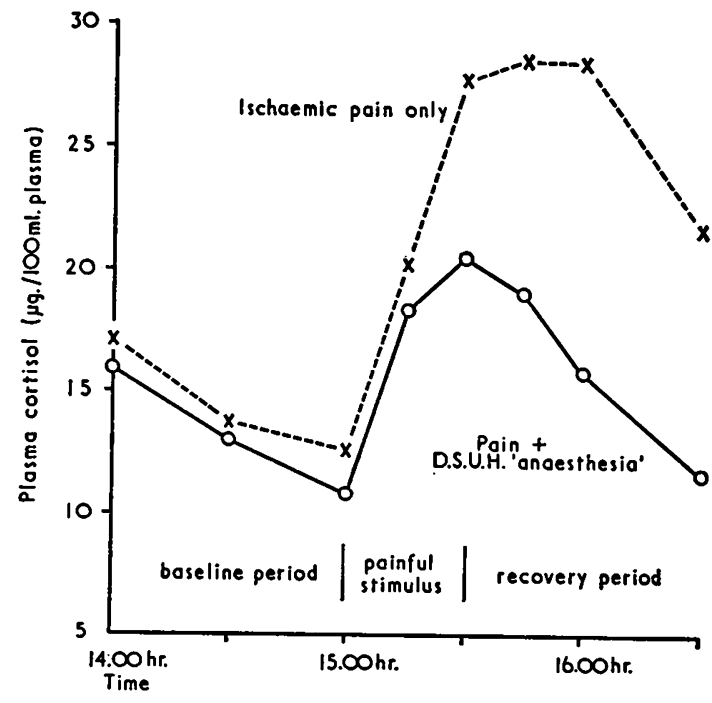

Fig. 2.-Mean response of five subiects (four female, one male) to ischaenic pain produced by immersion of the forearm in wet ice was a marked rise in the plasma cortisol levels, but in the presence of the same stimulus after D.S.U.H. of total anaesthesia of the affected arm this rise was significantly reduced. 
TABLE IV

\begin{tabular}{|c|c|c|c|c|c|c|c|c|c|c|c|c|c|c|c|c|c|c|c|c|c|}
\hline \multirow{4}{*}{ Subject } & \multirow{4}{*}{ Sex } & \multicolumn{20}{|c|}{ Plasma Cortisol ( $\mu \mathrm{g} . / 100 \mathrm{ml})}$. \\
\hline & & \multicolumn{10}{|c|}{ Ischaemic Pain per se } & \multicolumn{10}{|c|}{ Ischaemic Pain and Hypnotic Anaesthesia } \\
\hline & & \multicolumn{3}{|c|}{$\begin{array}{c}\text { Resting Baseliné } \\
\text { at (min.) }\end{array}$} & \multicolumn{2}{|c|}{$\begin{array}{c}\text { Ischaemic } \\
\text { Pain at (min.) }\end{array}$} & \multicolumn{3}{|c|}{$\begin{array}{l}\text { Recovery Period } \\
\text { at (min.) }\end{array}$} & \multirow{2}{*}{$\begin{array}{l}\text { Maxi- } \\
\text { mum } \\
\text { Level }\end{array}$} & \multirow{2}{*}{$\begin{array}{l}\text { Maxi- } \\
\text { mum } \\
\text { Incre- } \\
\text { ment }\end{array}$} & \multicolumn{3}{|c|}{$\begin{array}{c}\text { Resting Baseline } \\
\text { at (min.) }\end{array}$} & \multicolumn{2}{|c|}{$\begin{array}{l}\text { Pain Stimu-| } \\
\text { lus at (min.) }\end{array}$} & \multicolumn{3}{|c|}{$\begin{array}{l}\text { Recovery Period } \\
\text { at (min.) }\end{array}$} & \multirow{2}{*}{$\underset{\text { maxi- }}{\text { Mevel }}$} & \multirow{2}{*}{$\begin{array}{l}\text { Maxi- } \\
\text { mum } \\
\text { Incre- } \\
\text { ment }\end{array}$} \\
\hline & & $\mathbf{0}$ & 30 & 60 & 15 & 30 & 15 & 30 & 60 & & & $\mathbf{0}$ & 30 & 60 & 15 & 30 & 15 & 30 & 60 & & \\
\hline $\begin{array}{l}5 \\
2 \\
6 \\
7 \\
8\end{array}$ & $\begin{array}{l}\mathbf{M} \\
\mathbf{P} \\
\mathbf{P} \\
\mathbf{P} \\
\mathbf{F}\end{array}$ & $\begin{array}{r}10.8 \\
18.8 \\
17.0 \\
+13.2 \\
25.0\end{array}$ & $\begin{array}{r}10.8 \\
13.0 \\
12.4 \\
8.8 \\
24.2\end{array}$ & $\begin{array}{r}9.2 \\
11.2 \\
11.4 \\
7.2 \\
24.0\end{array}$ & $\begin{array}{l}19.0 \\
14.2 \\
13.8 \\
19 \cdot 4 \\
34.8\end{array}$ & $\begin{array}{l}23.6 \\
21.8 \\
21.2 \\
44.0\end{array}$ & $\begin{array}{l}33.6 \\
20.8 \\
25.4 \\
19 \cdot 6 \\
39.4\end{array}$ & $\begin{array}{l}30 \cdot 2 \\
23.6 \\
32 \cdot 2 \\
20.0 \\
35.8\end{array}$ & $\begin{array}{c}\overrightarrow{18.8} \\
29.6 \\
13.0 \\
26.2\end{array}$ & $\begin{array}{l}33.6 \\
23.6 \\
32.2 \\
21.2 \\
44.0\end{array}$ & $\begin{array}{l}24.4 \\
12 \cdot 4 \\
20 \cdot 8 \\
14 \cdot 0 \\
20.0\end{array}$ & $\begin{array}{r}12.2 \\
10.4 \\
* 10.4 \\
12.6 \\
* 35.0\end{array}$ & $\begin{array}{r}11.4 \\
8.2 \\
9.4 \\
8.8 \\
27.8\end{array}$ & $\begin{array}{r}11.0 \\
6.6 \\
8.0 \\
5.8 \\
23.2\end{array}$ & $\begin{array}{l}17 \cdot 8 \\
11.4 \\
12 \cdot 4 \\
16.6 \\
32.2\end{array}$ & $\begin{array}{l}17.0 \\
20.6 \\
15.6 \\
17.6 \\
32.8\end{array}$ & $\begin{array}{l}14 \cdot 0 \\
22 \cdot 4 \\
16 \cdot 2 \\
14 \cdot 0 \\
28 \cdot 6\end{array}$ & $\begin{array}{l}13.0 \\
17.8 \\
13.4 \\
11.8 \\
23.4\end{array}$ & $\begin{array}{r}11.8 \\
11.4 \\
11.2 \\
8.0 \\
20.6\end{array}$ & $\begin{array}{l}17.8 \\
22.4 \\
16.2 \\
17.6 \\
32.8\end{array}$ & $\begin{array}{r}6.8 \\
15.8 \\
8.2 \\
11.8 \\
9.6\end{array}$ \\
\hline
\end{tabular}

rise was recorded during hypnotic anaesthesia in the presence of painful stimulus, the difference of the means in the two experiments on the same subject was not significant during the baseline period at 0,30 , and 60 minutes, whereas during arm immersion in ice the difference was significant at 15 minutes $(\mathbf{P}<0.001)$. But, while at $\mathbf{3 0}$ minutes in four subjects there was always a difference in the same direction, the Student's $t$ with three degrees of freedom- $t_{3}$-nevertheless works out at 2.83, $\mathrm{P}<0.10$. No sample, however, was obtained at 30 minutes from Subject 6, and the high cortisol levels found throughout in Subject 8 produce a wide scatter in the results. Unknown to us until after the first experiment, Subject 8 (F.), was on megestrol acetate, but both experiments on her were performed at the same epoch in the menstrual cycle. During the recovery period for all subjects the difference of the means was not significant at 15 minutes, while at 30 minutes $t_{4}=5.0, P<0.01$, and at 60 minutes, with another sample missing (Subject 5), $t_{3}=2.89, P<0.10$. Fig. 2 shows the mean results of these five experiments on pain per se and suggested hypnotic anaesthesia.

\section{Effect of Hypnotically Suggested Pain in Absence of Painful Stimulus}

Following hypnotically suggested pain in the absence of painful stimulus, Subject 5 was apparently convinced that his arm was again immersed in ice as in (2) and (3), instead of in water at $37^{\circ} \mathrm{C}$, and reported variable pain described as "very bad" or "unpleasant." But the effect on the plasma cortisol levels in this single experiment was nil: at 0,30 , and 60 minutes of the resting baseline, $15.4,13.0$, and $11.4 \mu \mathrm{g}$. of cortisol per $100 \mathrm{ml}$. were recorded; during suggested pain at 15 and 30 minutes, 12.8 and $11.2 \mu \mathrm{g} . / 100 \mathrm{ml}$. ; and during the recovery period at 15,30 , and 60 minutes, $9.8,5.6$, and $6.4 \mu \mathrm{g} . / 100 \mathrm{ml}$. The maximum level was thus the initial resting level, $15.4 \mu \mathrm{g} . /$ $100 \mathrm{ml}$. , and the maximum increment $1.4 \mu \mathrm{g}$.

\section{Discussions and Conclusions}

As may be deduced from the work on hand and forearro blood flow by Black et al. (1963), the nice distinctions made by Black (1965) between D.S.U.H., I.S.U.H., and P.H.S. may sometimes be important in relation to physiological responses. Thus Black at al. (1963) showed in general that D.S.U.H. of being "hot"-as in "You are hot"-produced no significant change in hand and forearm blood flow, but in two subjects I.S.U.H. involving anxiety-as in "You are hot because the house is on fire "-elicited vasodilatations similar to the response described by Blair et al. (1959) as the result of fear. So far as the plasma cortisol levels are concerned our findings suggest, however, that such distinctions may be irrelevant.

It should be noted, nevertheless, that the "reality" of all hypnotic responses, whether psychological or physiological, has been questioned with the proposition that they are largely " histrionic" (Barber, 1961), and, as Black et al. (1963) showed, this can more often than not be the case. However, in at least one subject our results show that hypnotically induced emotion was "real" enough to produce a change in the plasma cortisol levels. A subject responding in this way to hypnotic suggestions of fear and anxiety thus provides a valuable "experimental animal " for any further investigation of the endocrinological and cerebral mechanisms involved. Moreover, it must be concluded clinically that in the investigation of suspected Cushing's syndrome a single cortisol level should be viewed with reserve because of possible emotional effects. Dynamic tests of adrenal function, such as dexamethasone suppression and A.C.T.H. stimulation, should therefore be employed (Ross et al., 1966).

In a more general finding hypnotically induced anaesthesia in five subjects produced a significant effect on the responses of the pituitary-adrenal axis to pain, indicating that this physiological reaction, at least, can be suppressed in such a way. In view of the subjective reports of feeling "nothing" in the presence of hypnotic anaesthesia, the constant though relatively slight rise recorcied in five subjects may well have been due to the effect of cold, and not to any residuum of pain, and in this respect the mean lowering of body temperatures by $0.6^{\circ} \mathrm{C}$. might be important. It may be noted, however, that the experimental production of pain per se without permanent trauma is difficult to achieve in other ways. The results of the single experiment on hypnotically suggested pain imply little, except that the physiological reaction here may parallel that of emotion when no objective response is recorded.

Investigating hypnotic sensory loss, Black and Wigan (1961) showed in conditioned reflex experiments that increased heart rate as the conditioned response was abolished in hypnotic selective deafness to tone of specific frequency presented as the conditioned stimulus, while Halliday and Mason (1964) and Black and Walter (1965) found that evoked non-specific frontal cortical responses were still present in both hypnotic deafness and peripheral hypnotic anaesthesia. To Black and Walter these findings suggested that the cerebral level where hypnotic blockade takes place-at least of hearing-probably lies at some point below projection of the input to non-specific frontal cortex, but above heart-regulating centres in the medulla. Our findings now suggest that such hypnotic blockade, at any rate of pain, must also take effect at the level of the hypothalamus.

\section{Summary}

The effects on the plasma cortisol levels of emotion and pain were variously investigated by hypnosis in eight deep-trance hypnotic subjects. It was found in three subjects out of four tested that hypnotic suggestions of "fear," "happiness," and " anxiety" had no effect on the plasma cortisol levels. In one subject, however, hypnotic suggestions of both fear and anxiety produced a rise in the plasma cortisol levels, while hypnotic suggestion of happiness had no effect. In five subjects tested it was found that, whereas ischaemic pain in the arm produced by cold caused a rise in the plasma cortisol levels, considerably smaller rises were recorded in the same subjects in the presence of hypnotic anaesthesia. In one subject it was found that hypnotically suggested pain in the absence of painful stimulus or cold produced no rise in the plasma cortisol levels. It is concluded that hypnotic suggestions of fear and anxiety can produce a rise in the plasma cortisol levels in some subjects and that suggestions of happiness probably do not. It is also 
concluded that suggested hypnotic anaesthesia effectively prevents the full rise in cortisol levels usually produced by painbut may have no effect on the physiological response to cold in this respect.

Our thanks are due to the Nuffield Fuundation for their support of the Wilton Crescent Research Unit in Psychophysiology and to Mrs. Pamela Bradbury, of the Division of Human Physiology of the Medical Research Council, for her statistical analysis of the results.

\section{REFERENCES}

Barber, T. X. (1961). Psychol. Bull., 58, 390.

Black, S. (1963). Brit. med. 7., 1, 925

(1965). In Proceeaings of Society of Psychosomatic Research Conference, 1962, edited by P. Hopkins and H. H. Wolff, p. 59.
Black, S., Edholm, O. G., Fox, R. H., and Kidd, D. J. (1963). Clin. Sd. $25,223$.

__ and Friedman, M. (1965). Brit. med. Y., 1, 562.

- and Walter, W. G. (1965). 7. Psychosom. Res., 9, 33.

- and Wigan, E. R. (1961). Brit. med. 7., 2, 736.

Blair, D. A., Glover, W. E., Greenfield, A. D. M., and Roddie, I. C (1959). \%. Physiol. (Lond.), 148. 633.

Friedman, M. (1965). Plasma Hydroxycorticosteroids in Pathological and Physiological States in Man, M.D. Thesis, University of Witwatersrand.

Halliday, A. M., and Mason, A. A. (1964). 7. Neurol. Neurosurg. Psychrat., 27, 300.

Hill, S. R., et al. (1956). Arch. intern. Med., 97, 269.

Landon, J., Wynn, V., and James, V. H. T. (1963). F. Endocr., 27, 183. Matungly, D. (1962). J. clin. Path., 15, 374.

Ross, E. J., Marshall-Jones, P., and Friedman, M. (1966). Quart. 7. Med., $35,149$.

Schally, A. V., Andersen, R. N., Lípscomb, H. S., Long, J. M., and Guillemin, R. (1960). Nature (Lond.), 188, 1192.

Werler, B. C., Dolgin, A. E., and Tryczynski, E. W. (1957). Endocrino$\log y, 61,300$.

\title{
Bilateral Selective Vagotomy in Prevention of Post-vagotomy Diarrhoea
}

\author{
MAURICE J. N. FROHN,*M.B., F.R.C.S. ; SURESH DESAI, † M.B., F.R.C.S. ; HAROLD BURGE, $\ddagger$ M.B., F.R.C.s.
}

Brit. med. F., 1968, 1, 481-483

Because of Dragstedt's work, vagotomy is fast spreading in all countries as the standard surgical treatment of duodenal ulceration. The operation as usually performed divides both vagus nerves as soon as they enter the abdomen. The anterior nerve trunks are divided above their hepatic branches-the liver, biliary system, pylorus, prepyloric stomach, and in part the Juodenum are therefore all denervated, as well, probably, as zome portion of the pancreas. The posterior nerve is divided sbove the coeliac division, and so the pancreas, the small and iarge gut, and other abdominal organs lose their vagal innervaison.

This operation, which is still routinely performed in most centres, is now usually referred to as total abdominal vagotomy. Persistent episodic diarrhoea is a serious complication of $i t$. In the episodic attacks liquid motions may be passed, with lmost no varning, into the clothes. The recorded incidence of severe diarrhoea depends on the definition of severity used by the investigator. Like dumping after gastrectomy, both the incidence and the severity are closely related to the thoroughness of follow-up studies.

Many surgeons do not think that post-vagotomy diarrhoea is a common or serious problem. However, there seem to be no studies published to support such a view; on the contrary, when the subject has been studied with care the findings appear to be uniform, in spite of the difficult problem of defining and classifying this complication (Table I).

- Research Registrar, West London Hospital, London W.6. + Registrar, West London Hospital, London, W.6. $\$$ Surgeon, West London Hospital, L London W.6.
The different types of selective vagotomy are shown in Fig. 1, while total abdominal vagotomy is shov:n in Fig. 2. Since 1958 we have used at the West London Hospital selective vagotomy in every case. The early results seemed to indicare that it was necessary to perform bilateral selective nerve section to obtain the best results (Burge, 1960). Further combined studies at the West London Hospital and the Glasgow Royal Infirmary confirmed the incidence and severity of diarrhcea after total abdominal vagotomy, but suggested that anterior selective nerve section was more important than posterior selective nerve section in the prevention of this complication. This conclusion has not been confirmed by the present study.

\begin{tabular}{|c|c|c|}
\hline \multirow{2}{*}{ Authors } & \multicolumn{2}{|c|}{ Incidence of Diarrhoea } \\
\hline & Total & Severe \\
\hline $\begin{array}{l}\text { Pollock (1952) (V. and G-E.) } \\
\text { American Gastroenterological } \\
\text { Association }\end{array}$ & $\begin{array}{l}16 \% \\
26 \% \\
38 \% \\
28 \% \\
27 \% \\
23 \% \\
30 \%\end{array}$ & $\begin{array}{l}7 \% \\
= \\
6.5 \% \\
5 \% \\
8 \%\end{array}$ \\
\hline
\end{tabular}

This study was planned to determine the importance of bilateral rather than anterior selective nerve section in the prevention of post-vagotomy diarrhoea. The series includes 321 cases-181 with anterior selective and 140 with bilateral selective nerve section.

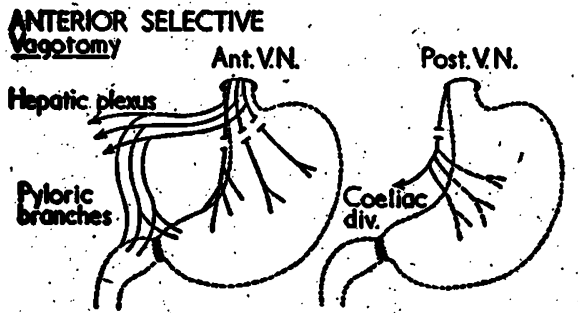

D

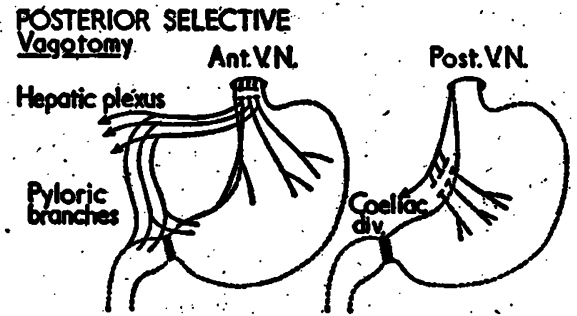

FIG. 1.-Different types of selective vagotomy.

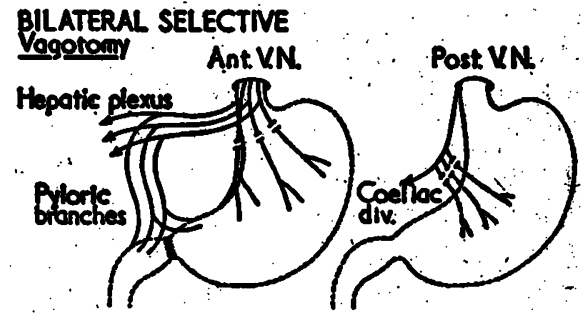

